\title{
Investigation of Pegmatite Mineral Applicability from the Terek Ceramic Deposit in Kyrgyzstan for Production of Porcelain and Earthenware
}

\author{
Mairam Abdullaeva1, Bektemir Murzubraimov², Dilbar Altybaeva3 ${ }^{3}$ Zhypargul Abdullaeva ${ }^{*}$ (i), \\ Gulzada Kalykova', Aishakan Suiunbekova', Aitgul Osmonova' \\ ${ }^{1}$ Department of General Chemistry, Osh State University, Osh, Kyrgyzstan \\ ${ }^{2}$ Institute of Chemistry and Phytotechnology, National Academy of Sciences, Bishkek, Kyrgyzstan \\ ${ }^{3}$ Department of Physical, Analytical, Organic Chemistry and Chemical Technologies, Osh State University, Osh, Kyrgyzstan \\ ${ }^{4}$ Science and Research Department, Osh State University, Osh, Kyrgyzstan \\ Email: *jypar.science@oshsu.kg
}

How to cite this paper: Abdullaeva, M. Murzubraimov, B., Altybaeva, D., Abdullaeva, Z., Kalykova, G., Suiunbekova, A. and Osmonova, A. (2021) Investigation of Pegmatite Mineral Applicability from the Terek Ceramic Deposit in Kyrgyzstan for Production of Porcelain and Earthenware. Journal of Minerals and Materials Characterization and Engineering, 9, 169-179. https://doi.org/10.4236/jmmce.2021.92012

Received: January 5, 2021

Accepted: March 13, 2021

Published: March 16, 2021

Copyright ( 2021 by author(s) and Scientific Research Publishing Inc. This work is licensed under the Creative Commons Attribution International License (CC BY 4.0).

http://creativecommons.org/licenses/by/4.0/

\begin{abstract}
This article is investigating analysis and chemical composition of ceramic pegmatite minerals obtained from the Terek deposit in Toktogul district of Kyrgyzstan. Several methods such as mineralogical studies, magnetic and gravitational enrichments, silicate and chemical analyses of ceramic pegmatite minerals, quartz-feldspathic concentrate and sludge removal have been performed for determination of pegmatite mineral applicability for production of porcelain and earthenware.
\end{abstract}

\section{Keywords}

Ceramic Pegmatite, Quartz-Feldspar Concentrate, Sludge, Magnetic Enrichment, Gravitational Enrichment, Iron Oxides, Spectral and Chemical Analysis

\section{Introduction}

Pegmatite research, origin and classification of minerals have interesting geoscientists for well over a century [1]. Based on the depth of formation, pegmatites are classified into: 1) Abbysal (AB) is high grade, high to low pressure; 2) Muscovite (MSC) is a high pressure, lower temperature; 3) Muscovite REL (rare element) is also abbreviated as MSREL, transitional between MSC \& MSREL; 4) Rare-Element (REL) is a low temperature and pressure; 5) Miarolitic (MI) is a shallow level [2]. Pegmatite was defined as an igneous rock of predominantly granitic composition, possessing properties such as: extremely coarse and syste- 
matically variable crystals size, abundance of crystals with skeletal, graphic or other strongly directional growth, and prominent spatial zonation of mineral assemblages, including monomineralic zones [3].

Ceramic pegmatite is composed exclusively of potassium feldspar or albite with quartz or nepheline and small amounts of other minerals, used as a raw material for the production of ceramics. Ceramic pegmatites include the so-called pure line granite pegmatites, according to Fersman, an example of which are the pegmatite fields of North Karelia, Ukraine and the Urals; hybrid pegmatites among carbonate pegmatites, composed mainly of microcline-perthite with an admixture of quartz, tremolite, phlogopite, diopside and other minerals (pegmatites of the state of New York, USA); desilicated granite pegmatites among ultrabasic pegmatites, represented by albitites; alkaline nepheline pegmatites, composed mainly of potassium feldspar and nepheline with an admixture of biotite, aegirine, zircon, and other minerals (pegmatites of the Vishnevy Mountains, Ural). The largest deposits of ceramic pegmatite are the Precambrian pegmatite fields of Karelia and Ukraine, Sweden, Norway, and the USA [4].

\section{Research Methods}

In this work, we enriched pegmatite minerals obtained from ceramic pegmatite deposit Terek of Toktogul region in Kyrgyzstan for application in ceramic, porcelain manufacturing and construction industries. Spectroscopy analyses were useful in the investigation of $\mathrm{H}_{2} \mathrm{O}$ and $\mathrm{OH}$ molecules presence in the structure of pegmatite samples. Gravitational enrichment of ceramic pegmatite was presented, where the optimal experimental method for producing of quartz-feldspar concentrate purified from iron oxides, a raw material for the production of fine ceramics was established.

\section{Characterization of Pegmatite and Sample Preparation}

In our work, we characterized pegmatite minerals obtained from the Terek deposit as shown in the geological map (Figure 1) for above purposes, and the structural-tectonic plan of this ceramic pegmatite deposits has trapezoid shape, elongated in North-Kokirimsky rift with square of $4 \mathrm{~km}^{2}$ on its South-Western ring. Basic relief forming index is wide flattened dry river valley Kargysh, binding with the Ketmen-Tube passage in North. These tectonic blocks characterized by white marble, bright color marbleized, stripped line and ribbon layered limestone tiles. Predicted resources of a pegmatite minerals stretched over $400 \mathrm{~m}$, with an average thickness of $45 \mathrm{~m}$, to a depth of $100 \mathrm{~m}$ is 1.8 million $\mathrm{m}^{3}$ or 5 million tons [5]. Presence of iron degrades electrical insulation properties of pegmatite, reduces whiteness and strength of the products, and leads to the formation of a "fly" and increase in the porosity of "electro-porcelain". In this regard, research work carried out to reduce the content of iron $\left(\mathrm{FeO}, \mathrm{Fe}_{2} \mathrm{O}_{3}\right)$ in the composition of quartz-feldspar concentrates.

Five ditches with a total volume of $254.4 \mathrm{~m}^{3}$ were passed to the Terek deposit 


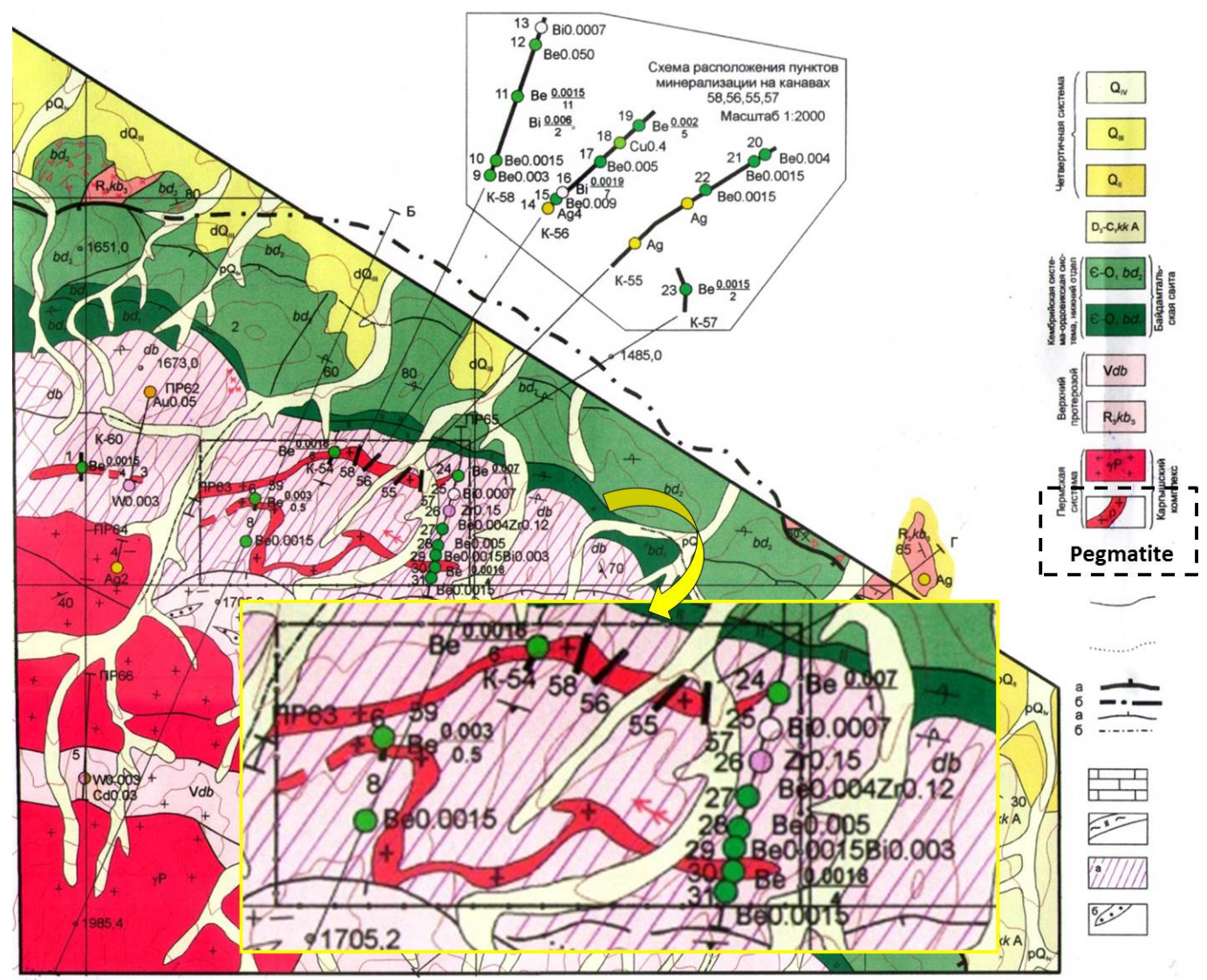

Figure 1. Geological map of Terek deposit showing location of pegmatite minerals. TP-2 ceramic pegmatite samples in our work have been obtained from ditches 55 - 56.

of ceramic pegmatite, 183 point samples were taken along the pegmatite deposits, 29 furrow and 31 dotted furrow samples were taken from the host rocks. Technological sample No.2 was selected from the main outcrop between ceramic pegmatite canals 56 and 55 by mechanical separation method. From the point samples and the technological samples, one average sample was selected, according to which we have conducted research. In this study, a working sample of $85.2 \mathrm{~g}$ was taken, obtained after the fourth quartering of the initial sample of ceramic TP-2 pegmatite (Figure 2), weighing $1300 \mathrm{~g}$. After sifting through sieves $(2 / 20) \mathrm{mm}$ from the initial sample weighing $85.2 \mathrm{~g}$, the following three fractions were obtained: $1 .(-10 \mathrm{~mm}),(+2 / 20 \mathrm{~mm})=60.8 \mathrm{~g} ; 2 .(-2 / 20 \mathrm{~mm}),(+1 \mathrm{~mm})=17$ g; 3. $(-1 \mathrm{~mm})=7.0 \mathrm{~g}$.

Sequence of experimental procedure steps on gravitational (by using the mills and mortar) and magnetic enrichments (on paper with magnet) ceramic pegmatite mineral samples shown in Figure 3. By the course of experiment, each fraction was individually crushed and passed through a sieve with pore size of $d=1$ $\mathrm{mm}$. A yellowish color powders with small black inclusions were observed. Each fraction was grinded in an aqueous medium and sludge was separated by elution, after which the powder colors of the fraction except $(-10 \mathrm{~mm}),(+2 / 20$ $\mathrm{mm}$ ) became transparent. Each fraction was individually subjected to magnetic 

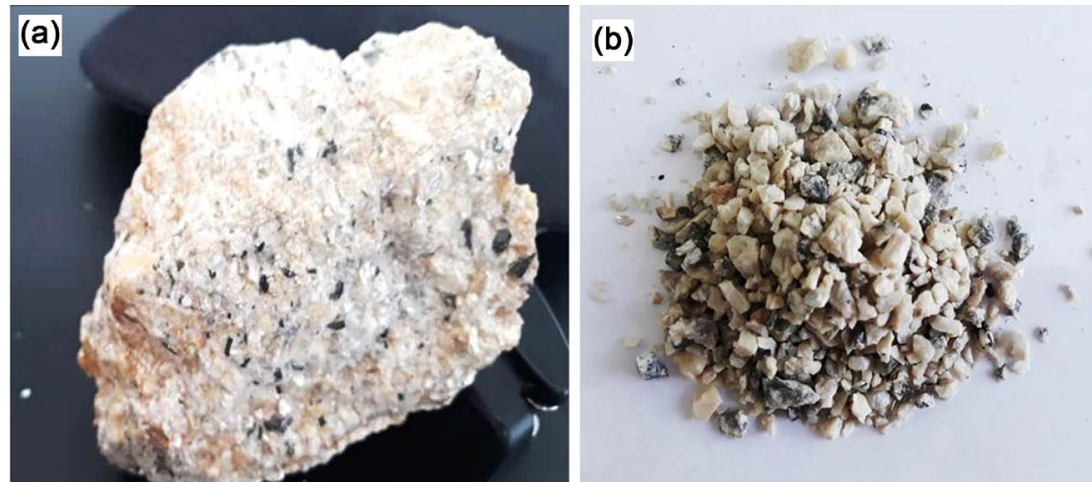

Figure 2. Initial sample of ceramic TP-2 pegmatite.

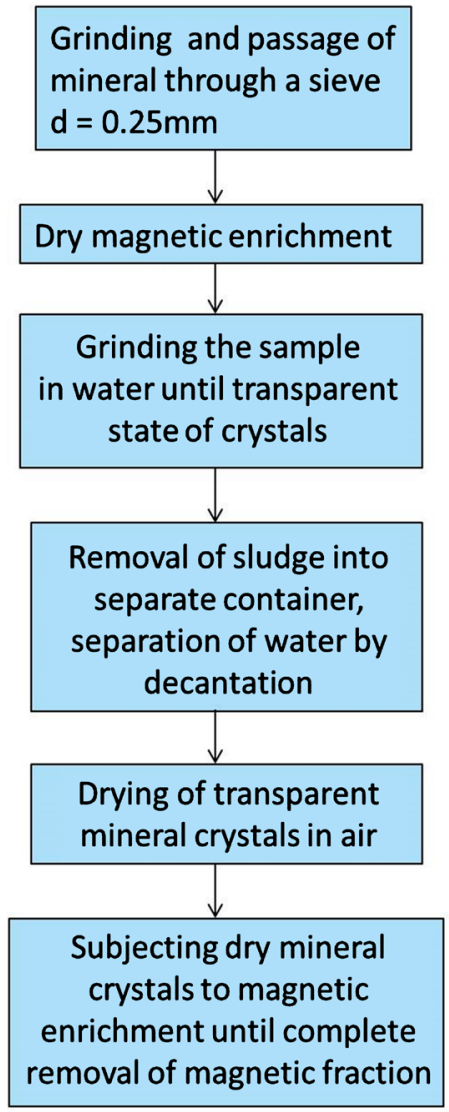

Figure 3. Experimental procedures of ceramic pegmatite TP-2 samples gravitational and magnetic enrichments.

separation, resulting in formation of $4.2 \mathrm{~g}$ iron-containing minerals, and $73.0 \mathrm{~g}$ of quartz-feldspar concentrate. The mass of obtained sludge was $41.0 \mathrm{~g}$. Figure 4 and Figure 5 are showing TP-2 pegmatite samples magnetic fraction after magnetic enrichment which was crushed in a porcelain ball mill to the state of powder (from the fraction $\mathrm{d}=-1 \mathrm{~mm}$ ), respectively.

\section{Results and Discussions}

Pegmatite containing granite is used as raw material for industrial minerals in 

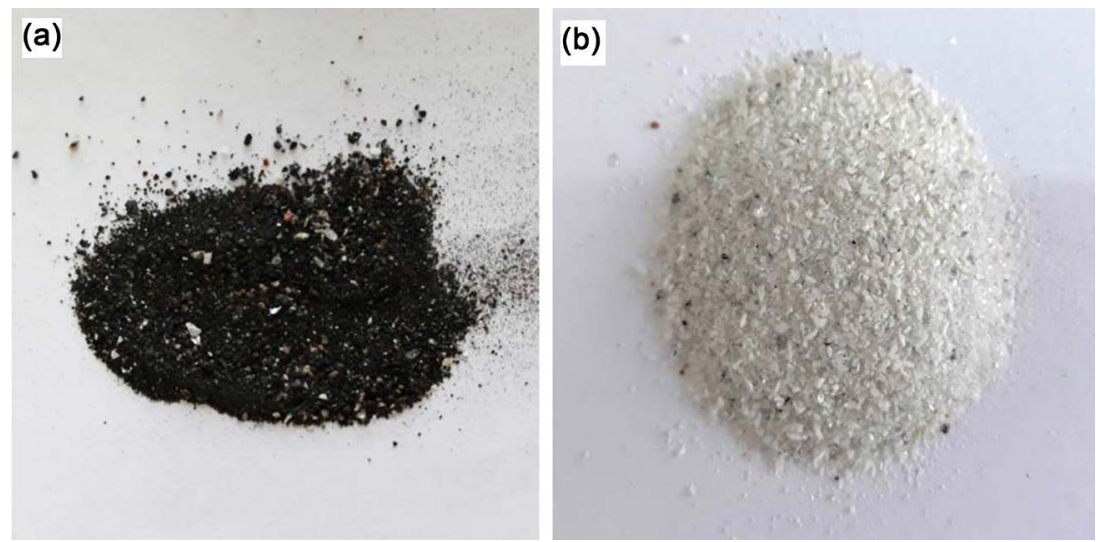

Figure 4. TP-2 sample: (a) magnetic fraction; (b) after magnetic enrichment.

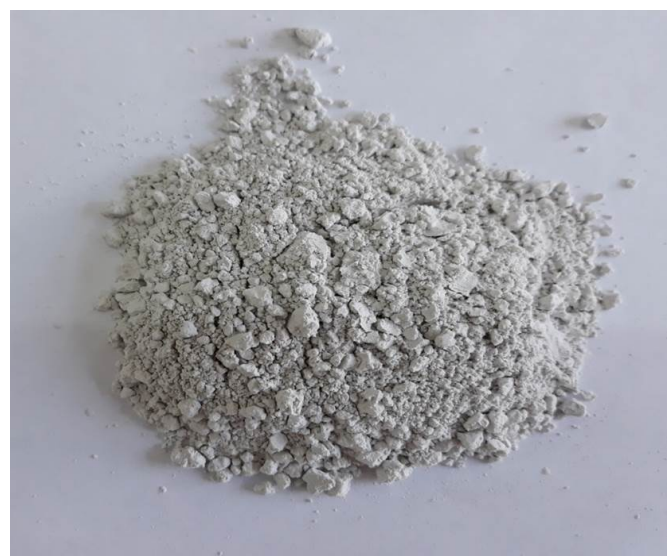

Figure 5. The fraction after magnetic enrichment, crushed in a porcelain ball mill to the state of powder (from the fraction $\mathrm{d}=-1 \mathrm{~mm}$ ).

the production of feldspar and quartz for glass, glass fiber, ceramic and porcelain [6]. Chemical composition and structure of pegmatite rocks were studied and analyzed in several works [7]-[12]. Location of pegmatites are typically zoned and possess an inner quartz core, a symmetrical intermediate zone of coarse-grained muscovite, quartz, microcline and minor plagioclase, and an outer border zone of fine-to medium-grained microcline, quartz, plagioclase and muscovite [13]. In addition, pegmatites are the source of high-quality industrial minerals feldspars, kaolinite, quartz, micas, and spodumene for ceramics or gemstones such as topaz, tourmaline, aquamarine, and spodumene [14].

An increase in the volume of construction and repair works in Kyrgyzstan determines increase in need of products as ceramic tiles, porcelain tiles, sanitary faience, glass for various purposes, heat, sound and electrical insulators, etc. First grade varieties of feldspars and pegmatites are suitable for manufacturing of fine art porcelain, high-quality electrical insulators; pegmatites of first and second grades are suitable for cooking porcelain and earthenware manufacturing. Third grade pegmatite is suitable for manufacturing of sanitary purpose ceramics and low-voltage insulators [15]. Technical requirements for chemical composition of ceramic raw materials regulate the content of iron $\left(\mathrm{FeO}, \mathrm{Fe}_{2} \mathrm{O}_{3}\right)$, which is a 
harmful impurity [16].

By using the chemical composition and chemical with technological characteristics of clay raw materials with initial components of earthenware ceramic products, a number of experimental works have been performed to select the optimal composition of earthenware mass containing ceramic pegmatite from the Terek deposit. To obtain the earthenware mass, the following initial rocks were prepared:

1) Ceramic pegmatite of the Terek deposit.

2) Naukat bentonite clay of the "Abshir" deposit.

3) White clay site "Beldeme" in Tash-Kumyr.

4) Pure quartz of the Suluktu deposit.

5) Chalk or waste from the production of shell limestone from the ZhalpakTash deposit of the Uzgen district.

The composition of the faience mass investigated which is consisting of the following components: pegmatite ceramic ( $90 \mathrm{~g})$, bentonite clay $(81 \mathrm{~g})$, white clay $(114 \mathrm{~g})$ and chalk $(15 \mathrm{~g}) .75 \mathrm{ml}$ of water was added to a sludge with a total weight of $300 \mathrm{~g}$. Selected amount of components was crushed together and ground in a porcelain mortar. Then $300 \mathrm{~g}$ of the mixture transferred to a mixing bowl with $75 \mathrm{ml}$ of water to obtain a ceramic dough, which was plastic as plasticine (Figure 6). After that, it wrapped in a plastic bag for 24 hours, and then round pieces with a thickness of $8-9 \mathrm{~mm}$ molded from it. The next day, after natural drying, they removed from the mold before burning; the samples dried for 2 hours at a temperature of $105^{\circ} \mathrm{C}-110^{\circ} \mathrm{C}$. The samples did not crack after drying. Then samples burned in an electric muffle furnace at a temperature of $900^{\circ} \mathrm{C}$ for an hour.

The mineralogical composition of the magnetic fraction with a mass of $4.2 \mathrm{~g}$ from a working sample TP-2 with a mass of $85.2 \mathrm{~g}$ was studied. Results of this study showed that magnetic fraction entirely consisted of tourmaline crystals

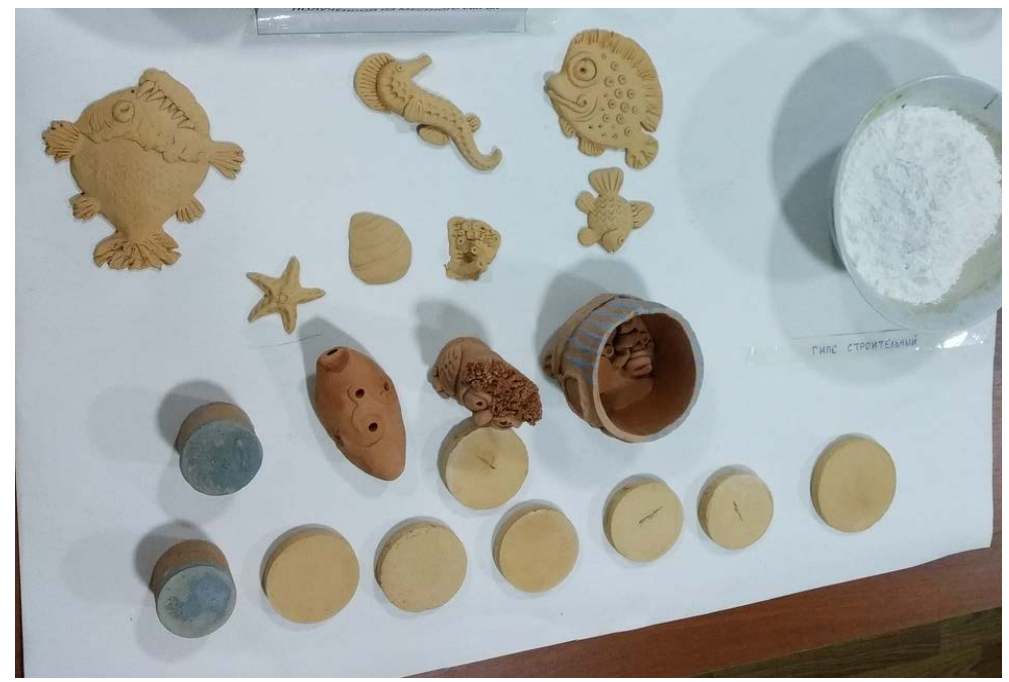

Figure 6. Some shaped products that can be used as souvenirs were prepared from samples of earthenware mass. 
with trigonal syngony; and prismatic tourmaline crystals of trigonal syngony with vertical hatching and properties such as shine: glassy, resinous; color: black; hardness: high; cleavage: perfect, and uneven fracture. Mineral components are in a good agreement with the technical requirements for chemical composition of ceramic raw materials GOST 7030-54 that are listed in Table 1. Spectral analysis results are shown in Table 2.

Results of silicate analysis given in Table 3 revealed that content of ceramic pegmatite minerals consisted of oxides $\mathrm{SiO}_{2}, \mathrm{FeO}, \mathrm{Fe}_{2} \mathrm{O}_{3}, \mathrm{TiO}_{2}, \mathrm{MnO}, \mathrm{Al}_{2} \mathrm{O}_{3}$, $\mathrm{CaO}, \mathrm{MgO}, \mathrm{K}_{2} \mathrm{O}, \mathrm{Na}_{2} \mathrm{O}, \mathrm{SO}_{3}$ and $\mathrm{P}_{2} \mathrm{O}_{5}$ corresponding to the granitic pegmatite

Table 1. Technical requirement for the chemical composition of ceramic raw materials in accordance with GOST 7030-54.

\begin{tabular}{cccccc}
\hline \multirow{2}{*}{ Content } & \multicolumn{2}{c}{ Fieldspars } & \multicolumn{3}{c}{ Pegmatite } \\
\cline { 2 - 5 } & $\mathbf{1}^{\text {st }}$ grade & $\mathbf{2}^{\text {nd }}$ grade & $\mathbf{1}^{\text {st }}$ grade & $\mathbf{2}^{\text {nd }}$ grade & $\mathbf{3}^{\text {rd }}$ grade \\
\hline $\mathrm{Fe}_{2} \mathrm{O}_{3}(\%)$ no more than & 0.2 & 0.3 & 0.2 & 8 & 0.5 \\
$\mathrm{~K}_{2} \mathrm{O}+\mathrm{Na}_{2} \mathrm{O}(\%)$ no less than & 12 & 11 & 8 & 2 & 8 \\
$\mathrm{CaO}(\%)$ no more than & 1 & 1 & 2 & 30 & 2 \\
$\mathrm{SiO}_{2}(\%)$ no more than & 8 & 10 & 30 & 0.3 & 30 \\
\hline
\end{tabular}

Table 2. Results of elemental composition analysis taken on grinded pegmatite mineral.

\begin{tabular}{|c|c|}
\hline Sample 1 & Sample 2 \\
\hline $\begin{array}{l}\text { Mn-15\%, Ni-0.5\%, Cr-2\%, Mo-0.15\%, Zr-0.4\%, } \\
\text { Cu-3\%, Pb-4\%, Ag-0.3\%, Zn-0.5\%, Sn-0.15\%. }\end{array}$ & $\begin{array}{c}\text { Mn-50\%, Ni-0.9\%, Co-1.2\%, Ti-2\%, Cr- } 1.5 \%, \\
\text { Mo-0.2\%, Zr-0.5\%, Cu-2\%, Pb-3\%, Ag-0.3\%, } \\
\text { Zn-0.5\%, Sn-0.2\%. }\end{array}$ \\
\hline
\end{tabular}

Table 3. Results of silicate analysis (test No. 458's) showing that iron oxides content was decreased after gravitational and magnetic enrichments.

\begin{tabular}{ccc}
\hline Mineral content & Initial sample & After gravitational and magnetic enrichments \\
\hline $\mathrm{SiO}_{2}$ & 72.45 & 73.91 \\
$\mathrm{FeO}$ & 0.61 & 0.05 \\
$\mathrm{Fe}_{2} \mathrm{O}_{3}$ & 0.55 & 0.1 \\
$\mathrm{TiO}_{2}$ & 0.03 & 0.02 \\
$\mathrm{MnO}$ & 0.05 & 0.05 \\
$\mathrm{Al}_{2} \mathrm{O}_{3}$ & 15.1 & 14.78 \\
$\mathrm{CaO}$ & 2.33 & 2.21 \\
$\mathrm{MgO}$ & 0.20 & 0.15 \\
$\mathrm{~K}_{2} \mathrm{O}$ & 3.41 & 3.52 \\
$\mathrm{Na}_{2} \mathrm{O}$ & 4.54 & 4.83 \\
$\mathrm{PPP}$ & 0.67 & 0.56 \\
$\mathrm{SO}_{3}$ & 0.1 & 0.1 \\
$\mathrm{P}_{2} \mathrm{O}_{5}$ & 0.1 & 0.1 \\
\hline
\end{tabular}


used as raw material for industrial minerals in the production of feldspar and quartz for glass, ceramic and porcelain [6].

Mineralogical composition studies of the quartz-feldspar concentrate weighing $73.0 \mathrm{~g}$ revealed its heterogeneity, consisting of microcline grains up to $60 \%$. Monoclinic syngonia was observed in prismatic and tabular crystals. Color: white; gloss: glass, cleavage: perfect (0110), fracture: conchoids and stepped. Quartz mineral was detected with trigonal syngony, occurring in the form of pyramidal crystals. Color is colorless, water-transparent, luster is glass, fracture is conchoidal, high hardness, and quartz is often penetrated by black, thin tourmaline crystals. Unopened quartz grains together with tourmaline make up to $20 \%$ of the fraction volume. Muscovite mineral with lamellar structure was observed. Monoclinic syngonia occurs in the form of flat-lamellar, narrowly scaly crystals. It splits into thin plates according to cleavage. Color is colorless, cleavage is perfect, and luster is glass. Muscovite lamellar structure contents were about $10 \%$ of the fraction volume.

Results of mineralogical studies of technological sample TP-2 showed that pegmatite of the ceramic deposit Terek is a quality raw material for fine ceramic products manufacturing [17] [18]. Experimental studies were conducted on the enrichment of pegmatite ceramic TP-2, the results of which showed the optimal course of the experiment: After conducting experimental research on gravitational and magnetic enrichment obtained: quartz-feldspar concentrate, sludge of less than 100 microns in size and magnetic fraction. Then, the quartz-feldspar concentrate was subjected to silicate analysis, and the sludge was subjected to spectral analysis. Sludge obtained after magnetic and gravitational enrichment of ceramic pegmatite and the initial sample of ceramic pegmatite were subject to spectral analysis at the Central Laboratory of the State Committee for Industry, Energy and Subsoil Use of the Kyrgyz Republic (Test Report No. 374). As can be seen from the results of spectral analysis, the pegmatite of the Terek ceramic deposit (Sample 1) and sludge (Sample 2) are containing valuable metals and rare-earth elements, which indicate the need for acid enrichment of the sludge in order to separate manganese, iron and other metals. Test report No. 458's shows the results of a chemical analysis of the initial sample and quartz-feldspar concentrate, which were carried out at the Central Laboratory of the State Committee for Industry, Energy and Subsoil Use of the Kyrgyz Republic. As can be seen from the results of the analysis, in the initial sample 1, the content of iron oxides were: $\mathrm{FeO}-0.61 \%, \mathrm{Fe}_{2} \mathrm{O}_{3}-0.55 \%$ in the amount of $1.16 \%$, and in the composition of quartz-feldspar concentrate sample 2 obtained after magnetic and gravitational enrichment, the content of iron oxides were: $\mathrm{FeO}-0.05 \%, \mathrm{Fe}_{2} \mathrm{O}_{3}-0.1 \%$ in the amount of $0.15 \%$. Results of chemical analysis confirmed that the quartzfeldspar concentrate obtained by us meets the requirements of GOST 7030-54. Thus, pegmatite of the ceramic deposit Terek of the Toktogul district can be used as raw material for ceramic and construction industries after gravitational and magnetic enrichments. 
Burned products had a natural monochromatic pinkish-red color, and ceramic pegmatite from the Terek deposit has the following advantages: high plasticity, low melting point $\left(900^{\circ} \mathrm{C}-950^{\circ} \mathrm{C}\right)$, high plasticity allowing to form complex and small products and preparation of terracotta, glazed, artistic and architecture products. The indicators of the earthenware mass were determined by using molded cylinders on a mold with size $\mathrm{h}=40 \mathrm{~mm} ; \mathrm{d}=40 \mathrm{~mm}$. Results of experiment on determining the properties of an earthenware mass showed that it has good exploitation properties: average molding moisture $20.69 \%$, average total shrinkage $8.86 \%$, average water absorption $14.2 \%$. Average water absorption and ultimate strength were also determined in the testing laboratory of the Republic Center for Certification and Construction of the State Agency for Architecture under Government of the Kyrgyz Republic, the test report of which indicates that the average water absorption is $14.6 \%$, and the compressive strength is 19.3 $\mathrm{mPa}$, which shows the high strength of the developed earthenware masses.

\section{Conclusions}

A literature review of the Terek ceramic pegmatite deposits showed positive potential due to the presence of ceramic raw materials, favorable geographic and economic conditions. Results of chemical analyses carried out at the Central Laboratory of State Committee for Industry, Energy and Subsoil Use of the Kyrgyz Republic confirmed the possibility of using pegmatite from the Terek ceramic deposit for porcelain and earthenware production after gravitational and magnetic enrichment. Mineralogical studies of TP-2 pegmatite samples from the Terek deposit showed that pegmatite meets the requirements of GOST 7030-54 can be used as high-quality raw material for manufacturing of fine ceramic products.

Optimal composition of the earthenware mass has been developed, consisting of the following components in weight percentage (wt.\%): ceramic pegmatite from the Terek deposit is 30\%; Naukat bentonite clay of Abshir deposit is 27\%; Tash-Kumyr white clay is $38 \%$; chalk waste from the production of shell rock from the Sary-Tash deposit of the Uzgen region is $5 \%$. Artistic ceramic items were prepared from the developed composition of the ceramic mass and their properties were investigated. Test report indicated advantages of the developed earthenware mass in terms of ceramic properties: high plasticity, indifference, low melting point and natural monochromatic pinkish-red color, which makes possible not to glaze faience products. The average water absorption of products is $14.6 \%$, and the compressive strength is $19.3 \mathrm{MPa}$, which shows the high strength of the developed faience mass. In summary, as a result of this research work, new environmentally friendly, cheap and waste-free technology for obtaining high-quality raw materials for fine and building ceramics was developed; and mixture combination of earthenware mass containing ceramic pegmatite from the Terek deposit, which has excellent performance and properties was obtained. 


\section{Conflicts of Interest}

The authors declare no conflicts of interest regarding the publication of this paper.

\section{References}

[1] Shaw, R.A., Goodenough, K.M., Roberts, N.M.W., Horstwood, M.S.A., Chenery, S.R. and Gunn, A.G. (2016) Petrogenesis of Rare-Metal Pegmatites in High-Grade Metamorphic Terranes: A Case Study from the Lewisian Gneiss Complex of NorthWest Scotland. Precambrian Research, 281, 338-362. https://doi.org/10.1016/j.precamres.2016.06.008

[2] Simmons, W.B., and Webber, K.L. (2008) Pegmatite Genesis: State of the Art. European Journal of Mineralogy, 20, 421-438. https://doi.org/10.1127/0935-1221/2008/0020-1833

[3] Steiner, B.M. (2019) Tools and Workflows for Grassroots Li-Cs-Ta (LCT) Pegmatite Exploration. Minerals, 9, 499. https://doi.org/10.3390/min9080499

[4] Paffengolts, K.N. (1987) Geological Dictionary. Volume II. Resp. “Nedra”, Moscow, $450 \mathrm{p}$.

[5] Popov, V.S. (2015) Report on the Results of Geological Explorations Conducted by the Takhtalyk Party for 2013-2015. Osh, SKGE.

[6] Hestnes, K.H., Aasly, K., Sandøy, R. and Sørensen, B.E. (2013) Occurrence of Iron in Industrial Granitic Pegmatite. Minerals Engineering, 52, 21-30. https://doi.org/10.1016/j.mineng.2013.03.004

[7] Hudleston, P.J. (1973) The Analysis and Interpretation of Minor Folds Developed in the Moine Rocks of Monar, Scotland. Tectonophysics, 17, 89-132. https://doi.org/10.1016/0040-1951(73)90067-X

[8] Gresens, R.L. (1967) Tectonic-Hydrothermal Pegmatites. Contributions to Mineralogy and Petrology, 16, 1-28. https://doi.org/10.1007/BF00371605

[9] Adetunji, A. and Can, O.O. (2010) Characterization and Mineralization Potentials of Granitic Pegmatites of Komu Area, Southwestern Nigeria. Resource Geology, 60, 87-97. https://doi.org/10.1111/j.1751-3928.2010.00116.x

[10] Akhmetshina, I.V., Karmazin, V.I., Mostyka, Y.S. and Shutov, V.Y. (1999) Technology of Magnetic Enrichment of Ceramic Raw Materials in Conditions of Incomplete Disclosure of Splices. Mountain Information Analytical Bulletin, 8.

[11] Grodnitsky, L.L. and Polin, A.K. (1975) Pegmatites of North Karelia and Their Aureole. Karelian Branch AS SSSR, Pertozavodsk, 201 p.

[12] Bukharova, O.V. and Marfin, A.E. (2018) Statistical Assessment of the Typochemical Features of Quartz in Granite Pegmatites. Geosphere Research, 2, 21-30. https://doi.org/10.17223/25421379/7/2

[13] Lottermoser, B.G. and Lu, J. (1997) Petrogenesis of Rare-Element Pegmatites in the Olary Block, South Australia, Part 1. Mineralogy and Chemical Evolution. Mineralogy and Petrology, 59, 1-19. https://doi.org/10.1007/BF01163059

[14] Gonçalves, A.O., Melgarejo, J.C., Alfonso, P., Amores, S., Paniagua, A., Neto, A.B., Morais, E.A. and Camprubí, A. (2019) The Distribution of Rare Metals in the LCT Pegmatites from the Giraúl Field, Angola. Minerals, 9, 580. https://doi.org/10.3390/min9100580

[15] Kozlovsky, E.A. (1975) Geology of the USSR. Volume XXV. Kyrgyz SSR. Minerals, Nedra, Moscow, 280 p. 
[16] Merga, A., Murthy, H., Amare, E., Ahmed, K. and Bekele, E. (2019) Fabrication of Electrical Porcelain Insulator from Ceramic Raw Materials of Oromia Region, Ethiopia. Heliyon, 5, e02327. https://doi.org/10.1016/j.heliyon.2019.e02327

[17] Abdullaeva, M.D., Altybaeva, D.T., Amatova, N.S. and Karimov, A. (2018) Mineralogical Studies of the Pegmatite of the Terek Ceramic Deposit in the Toktogul Region of Kyrgyzstan. Bulletin of the National Academy of Sciences of the Kyrgyz Republic, 5, 135-139.

[18] Abdullaeva, M.D., Altybaeva, D.T., Karimov, A., Osmonova, A.A. and Talaybek kyzy, U. (2019) Study of the Pegmatite of the Terek Ceramic Deposit in Kyrgyzstan as a Feldspar Raw Material for the Fine-Ceramic Industry. Abstracts of the 1 st Congress of Scientific Turkish-Speaking Countries, Osh, 22-23 April 2019, 33. 